Dicle Tıp Dergisi / Dicle Medical Journal (2017) 44 (1) : 35 - 41

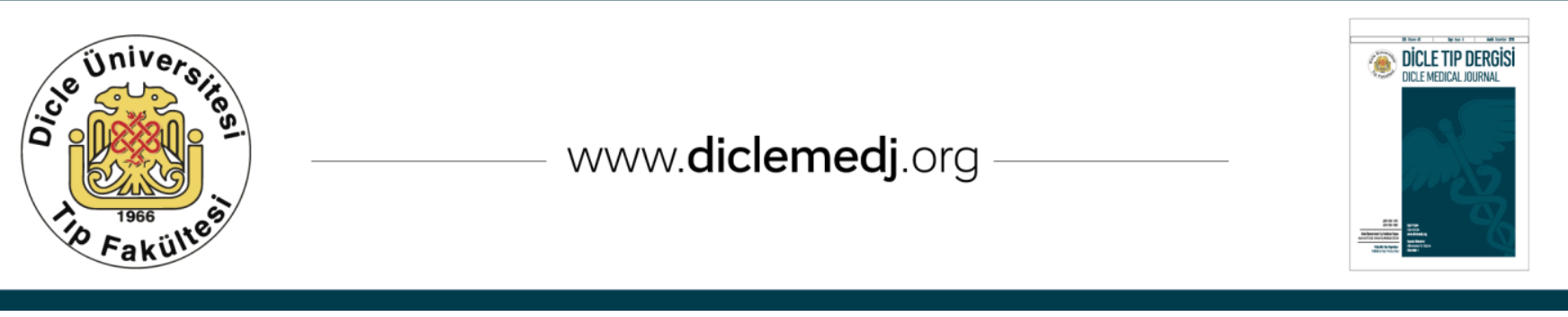

Original Article / Özgün Araştırma

\title{
Investigation of Serum Levels of Selenium, Zinc, and Copper in Adolescents with Idiopathic Scoliosis
}

\author{
Zahide Yalaki' ${ }^{1}$, H. Mustafa Ozdemir ${ }^{2}$, Tugba Zengin ${ }^{3}$, Metin Işik ${ }^{4}$ \\ 1 Ankara Training and Research Hospital, Pediatric Clinic Ankara, Turkey \\ 2 Acıbadem Hospital, Orthopedics and Traumatology, Ankara, Turkey \\ 3 Ulus State Hospital, Pediatric Clinic, Ankara, Turkey \\ 4 Ankara Training and Research Hospital, Orthopedics and Traumatology, Ankara, Turkey
}

Received:12.09.2016; Revised: 26.01.2017; Accepted: 09.02.2017

\begin{abstract}
Objective: The purpose of this study was to investigate the serum levels of selenium, zinc and copper on the etiology of idiopathic scoliosis in adolescents.

Methods: Forty four idiopathic scoliosis patients between 10 and 17 years of age were considered in this study. The vertebra curvature degrees of the patients were between $28^{\circ}$ and $82^{\circ}$. The idiopathic scoliosis patients were assigned to two groups based on their vertebra curvature degrees. Curvature degree of $45^{\circ}$ and lower was labeled as group 1 and curvature of upper $45^{\circ}$ was labeled as group 2 . Total blood count, serum levels of selenium, zinc and copper were studied.

Results: Thirty three of the idiopathic scoliosis patients (75\%) were female. There was no statistically significant difference in serum zinc and copper levels between idiopathic scoliosis patients and the control group ( $p>0.05)$. Serum selenium levels in idiopathic scoliosis patients were lower than that of the control group and the difference was statistically significant $(\mathrm{p}<0.05)$. In terms of vertebra curvature degree and demographic characteristics of the patients, group 2 age average was significantly higher than that of the group $1(\mathrm{p}<0.05)$. When serum selenium, zinc, and copper levels were compared based on the vertebra curvature degrees of the IS patients, no statistically significant difference was observed between group 1 and 2 in laboratory measurements $(p>0.05)$.

Conclusion: Among the measured trace elements, selenium was lower in the serum of the IS patients. This is the first study in Turkey that we know of about this subject and we think that further studies are needed.
\end{abstract}

Keywords: idiopathic scoliosis, selenium, zinc, copper

DOI: $10.5798 /$ dicletip.298579

Yazışma Adresi / Correspondence: Correspondig Autor: Zahide Yalaki, Ankara Training and Research Hospital, Pediatric Clinic Ulucanlar, Ankara, Turkey E-mail: $\underline{d r}$ zahide@yahoo.com 


\section{Adolesan İdiyopatik Skolyozda Serum Selenyum, Çinko ve Bakır Düzeylerinin Araștırılması}

\section{Özet}

Amaç: Bu çalışmada adolesanlardaki idiyopatik skolyozun etiyolojisinde serum selenium, çinko ve bakır düzeylerinin araştırılması amaçlanmıştır.

Yöntemler: Çalışmaya 10-17 yaş arası idiyopatik skolyozu olan 44 hasta alınmıștır. Hastaların vertebra eğrilik dereceleri 280 ile 820 arasında değiş̧iklik göstermiştir. İdiopatik skolyozlu hastalar vertebra eğrilik derecelerine göre 450 altı (grup 1) ve 450 üstü (grup 2) eğrilikler olarak 2 gruba ayrılmıștır. Çocuklarda tam kan sayımı, serum selenyum, çinko, bakır düzeyleri çalışılmıştır.

Bulgular: İdiyopatik skolyozlu hastaların 33'ü (\%75) kızdır. İdiopatik skolyozlu hastalar ve kontrol grupları arasında serum çinko ve bakır düzeylerinde istatistiksel olarak anlamlı farklılı görülmemiștir ( $p>0,05)$. İdiyopatik skolyozlu hastalarda kontrol grubuna göre serum selenyum düzeyi düşüktür ve istatistiksel olarak anlamlı bulunmuștur $(\mathrm{p}<0,05)$. Hastaların eğrilik dereceleri ve demografik özelliklerine bakıldığında, grup 2'nin yaş ortalaması, grup 1'e göre istatistiksel anlamlı olarak daha yüksektir $(\mathrm{p}<0,05)$. İdiopatik skolyozlu hastaların eğrilik derecelerine göre serum selenyum, çinko ve bakır düzeyleri karşılaştırıldığında grup 1 ile grup 2 arasında laboratuvar ölçümlerinde istatistiksel olarak anlamlı bir fark görülmemiştir ( $p>0,05)$.

Sonuç: Eser elementlerden olan selenyum idiopatik skolyozlu hastaların serumunda daha düşük bulunmuştur. Çalışmamız bu konuda Türkiye'de yapılan ilk çalışmalardan biridir ve daha geniş çaplı çalışmalara ihtiyaç olduğu düşünülmüştür.

Anahtar kelimeler: idiyopatik skolyoz, selenyum, çinko, bakır.

\section{INTRODUCTION}

Spinal distortions, especially scoliosis, are among the most frequent orthopedic deformations observed in children and adolescents [1]. Scoliosis is generally defined as lateral curvature of vertebra on the frontal plane $[2,3]$. It can cause physical bends of the body as well as cardiopulmonary complications in advanced stages. At the same time, it can cause emotional anxiety and cosmetic abnormalities [4-6].

It is reported that scoliosis is observed in a wide interval, between $0.2-6 \%$, and more frequently in adolescent girls around the world $[1-4,7]$. In Turkey, frequency of scoliosis was determined to be around $0.48 \%$ [5] and $0.47 \%$ [8], also more often among girls $[4,5,8]$. Treatment options of scoliosis differ based on the curvature degree of the vertebra. If the curvature degree is below $45^{\circ}$, medical and conservative treatment is preferred; if the curvature degree is over $45^{\circ}$, surgical treatment is considered [9].
Possibly congenital, however $75-80 \%$ of the scoliosis cases have no known reason (idiopathic). It may appear in a healthy child without being noticed and progress with skeleton development [4]. With early diagnosis, future complications of idiopathic scoliosis (IS) may be prevented, but its etiology is still not well known. It is thought that some biochemical, hematologic, hormonal factors may play a role in the beginning and progression of scoliosis [4,10-12].

In some studies, it was shown that essential trace elements necessary for the body (selenium, zinc, copper) have roles in synthesis of collagen and elastin and maturation of the body and therefore in the progression of IS $[10,11,13]$. Selenium, zinc, and copper show their functions through metalloenzymes. The absorption of these trace elements in the body, their transport in blood, and their metabolism in liver and target tissues are well known. Various studies have shown that deficiency of some trace elements, such as copper and 
selenium, may cause disruptions in collagen synthesis and maturation [14-16]. Some studies suggested that selenium deficiency is a risk factor for IS $[10,11,13]$; recent studies have also suggested that excess selenium is also a risk factor for IS $[17,18]$. Consequently whether deficiency or excess of selenium is a bigger risk factor is not yet known.

Our study contributes to the literature of studies about IS conducted in various countries by reporting cases from Turkey. In our study, we evaluated scoliosis patients' serum levels of selenium, zinc, and copper that take part in IS etiology. Also, because of the different correlations found between scoliosis patients and selenium levels in recent studies, we wanted to determine the relationship between selenium levels and IS patients in our hospital.

\section{METHODS}

44 IS patients between 10-17 years of age were considered in this study. Another group of 44 patients, in the same age group, who were admitted to our pediatric clinic for different reasons were taken as the control group. Physical examination of these patients did not reveal any evidence of scoliosis. Malnutrition, malabsorption, chronic systemic illnesses were not determined in the patient group with IS.

The vertebra curvature degrees of the patients were between $28^{\circ}$ and $82^{\circ}$. The IS patients were assigned to two groups based on Lenke classification [19]. According to this classification, Group 1 included patients that had $45^{\circ}$ and lower curvature, while group 2 patients had $45^{\circ}$ and upper curvature. Medical and surgical treatments were planned based on this grouping.

Calcium, phosphorus, alkaline phosphatase, total blood count, serum selenium, zinc and copper data obtained from the patients were studied. Atomic adsorption spectrophotometry (SPECTRAA) method was used to study selenium, zinc and copper in the plasma. The data of the study was analyzed with the SPSS 11.5 software program. The significance of the difference between means among groups was evaluated with Student's t-test and the significance of the difference between medians among groups was evaluated with Mann Whitney $U$ test. Nominal variables were evaluated with Fisher's Chi-Square test and $\mathrm{p}<$ 0.05 was accepted as statistically significant for all results. For this study, we obtained permission from the ethics committee of our hospital on 26 October 2011 with reference number 0438 .

\section{RESULTS}

$33(75 \%)$ of the IS patients were female and 11 (25\%) were male. Their average age was $14.8 \pm$ 1.7 (Table 1). There was no statistically significant difference in age and sex ratios between the IS patients and the control group.

Laboratory analysis results showed that calcium, phosphorus, and alkaline phosphatase levels in both groups were normal. Serum selenium levels in IS patients were lower than that of the control group and the difference was statistically significant $(\mathrm{p}<0.05)$ (Figure 1 ). However, there was no statistically significant difference in serum zinc and copper levels between the IS patients and the control group $(p>0.05)$. There was no difference in serum selenium/albumin, serum zinc/albumin ratios between the IS patients and the control group (p > 0.05) (Table 1).

In terms of vertebra curvature degree and demographic characteristics of the patients, group 2 age average was significantly higher than that of the group $1(\mathrm{p}<0.05)$ (Table 2). There was no statistically significant difference in terms of sex distribution among these groups ( $p$ > 0.05); however, 78.9\% of the group 2 patients were female. Conservative treatments were applied to group 1 patients, while surgical treatments were applied to group 2 patients. 
Table 1: Demographic Characteristics and Laboratory Measurement Values of Patient and Control Groups

\begin{tabular}{|c|c|c|c|}
\hline & $\begin{array}{c}\text { Patient } \\
\text { Group } \\
(\mathrm{n}=44)\end{array}$ & $\begin{array}{c}\text { Control } \\
\text { Group } \\
(\mathrm{n}=44)\end{array}$ & $\begin{array}{c}\text { p- } \\
\text { value }\end{array}$ \\
\hline Age & $14.8 \pm 1.6$ & $14.8 \pm 1.7$ & 0.898 \\
\hline \multicolumn{4}{|l|}{ Sex } \\
\hline Girls & $\begin{array}{c}33 \\
(\% 75.0)\end{array}$ & $\begin{array}{c}33 \\
(\% 75.0)\end{array}$ & \\
\hline Boys & $\begin{array}{c}11 \\
(\% 25.0)\end{array}$ & $\begin{array}{c}11 \\
(\% 25.0)\end{array}$ & \\
\hline Zinc (umol/L) & 14.6 & 15.2 & 0.276 \\
\hline Copper (umol/L) & 15.7 & 16.2 & 0.233 \\
\hline Selenium (umol/L) & 78.0 & 93.0 & 0.012 \\
\hline Selenium/Albumin & 18.2 & 19.7 & 0.054 \\
\hline Zinc/Albumin & 3.2 & 3.3 & 0.238 \\
\hline
\end{tabular}

When serum selenium, zinc, and copper levels were compared based on the vertebra curvature degrees of the IS patients, no statistically significant difference was observed between group 1 and group 2 in laboratory measurements $(\mathrm{p}>0.05)$ (Table 2$)$.

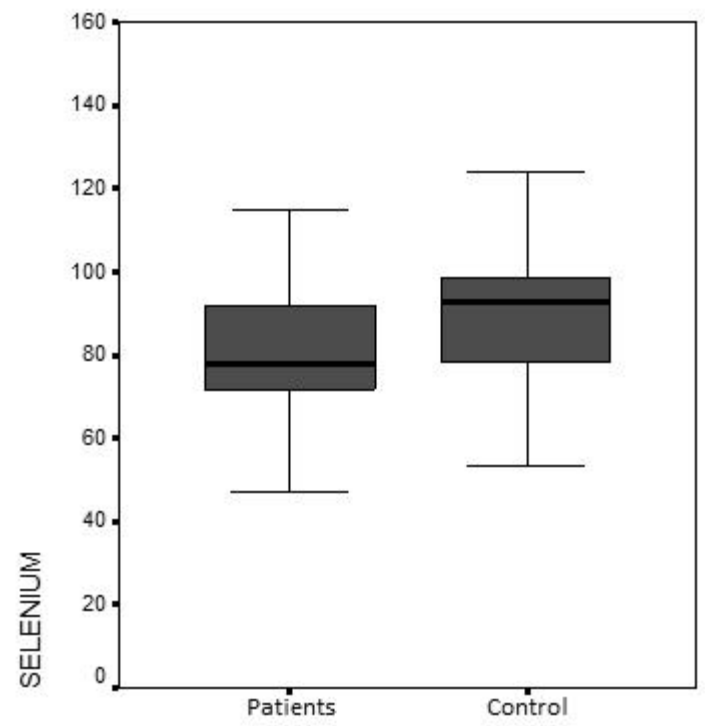

Figure 1. Selenium Level Distribution based on Patient and Control Groups
Table 2: Demographic Characteristics and Laboratory Measurement Values within Patient Group Based on Curvature Degree

\begin{tabular}{lccc}
\hline & $\begin{array}{c}\text { Group 1 } \\
(\mathbf{n = 6})\end{array}$ & $\begin{array}{c}\text { Group 2 } \\
(\mathbf{n = 3 8})\end{array}$ & $\begin{array}{c}\text { p- } \\
\text { value }\end{array}$ \\
\hline Age & $13.2 \pm 2.0$ & $15.0 \pm 1.4$ & 0.008 \\
Sex & & \multicolumn{3}{c}{0.154} \\
Girls & $3(\% 50)$ & 30 & $(\% 78.9)$ \\
Boys & $3(\% 50)$ & 8 \\
$(\% 21.1)$ & \\
Zinc (umol/L) & 12.7 & 14.9 & 0.131 \\
Copper (umol/L) & 13.9 & 15.8 & 0.907 \\
Selenium (umol/L) & 89.9 & 77.9 & 0.356 \\
Selenium/Albumin & 19.1 & 18.0 & 0.605 \\
Zinc/Albumin & 3.1 & 3.2 & 0.472 \\
\hline
\end{tabular}

\section{DISCUSSION}

Etiology of IS is still under discussion while genetic tendency is being considered. In various studies, melatonin, thrombocyte anomalies; body asymmetry; intervertebral disc anomalies and connective tissue anomalies were suggested to have an important place in IS etiology $[4,11,12,14]$.

Collagen and elastin are the structural components of fibril connective tissue. These are gene controlled enzymatic system products. Lysyl oxidase is the key copper dependent enzyme in the synthesis and maturation of collagen and collagen fibrils. A proper function of this enzyme system depends on the existence of all of the substrates, cofactors and sufficient quantities of multifunctional trace elements $[12,13]$. Se, $\mathrm{Zn}$ and $\mathrm{Cu}$ are important trace elements that take part in collagen synthesis and maturation. Se and $\mathrm{Zn}$ are transported by binding to albumin in the body. Their absorption decreases in cases of malabsorption and malnutrition [20,21]. Similarly, $\mathrm{Zn} / \mathrm{Cu}$ ratio is an indication of malabsorption and it decreases in cases of protein energy malnutrition, malabsorption, and chronic systemic illnesses [22,23]. In our 
study, evaluation of patients did not reveal indications of malnutrition and malabsorption; $\mathrm{Zn} / \mathrm{Cu}$, Se/Albumin, and $\mathrm{Cu}$ /Albumin levels were normal.

Data analysis revealed that, of the trace elements, selenium was lower in the serum of the IS patients compared to the control group, while serum zinc and copper levels and zinc/copper ratios were found to be normal. When similar studies in the literature were reviewed, these findings were supported. However, interpretation of the risks associated with various serum selenium levels is far from certain. The cause of selenium deficiency is not well known, however, some authors suggest low levels of selenium in the soil and environment may be a factor $[15,24]$. Variations in selenium levels in the environment may be the cause of selenium deficiency in our patients as well.

In some studies, serum selenium levels were found to be low in the scoliosis patients $[10,13,14]$. In a study for example, selenium levels both in the serum and in hair samples were found to be low in IS patients [14]. Dastych et al. compared vertebra curvature levels with serum selenium, zinc, and copper levels in their study and found that patients with more than $45^{\circ}$ curvature who required surgical treatment had significantly lower levels of serum selenium and serum/albumin ratio compared to patients with less than $45^{\circ}$ curvature [10]. In our study, we did not find statistically significant difference between curvature levels and serum levels of selenium, zinc, and copper; however, we found that serum selenium levels in IS patients were significantly lower compared to the control group.

Contrary to other studies, in an experimental study, Yang et al. suggested that high level of selenium is also a risk factor for IS [17]. In some studies, it is reported that high selenium levels in the environment could be a risk factor for scoliosis. In a study about fish, Lemly et al. reported that pollution caused by a thermoelectric power plant produced high levels of selenium in a lake in the USA. This pollution was linked to observed scoliosis in the fish found in the lake [25]. In another study, Ji et al. reported that two towns in China have the highest levels of environmental selenium in the world. In these towns, IS is observed more often in adolescents [18]. These results show that changes in selenium levels is an important risk factor in IS development. However, it is not clear whether the deficiency of selenium, based on Datch et al. study and our study, or, the excess of selenium is a more important risk factor. This situation merits wider studies.

In the study, conducted by Dastych et al., copper levels and zinc/copper ratios in IS patients' serums were found to be low; however, difference was not statistically significant [10]. In another study, serum copper and zinc levels were found to be normal in IS patients [13]. In a different study conducted by Dastych et al., copper levels in the back muscles of IS patients were found to be low, but no significant difference was found in hair, leucocyte, and serum compared to the control group [26]. In our study, IS patients' serum zinc and copper levels and zinc/copper ratios were found to be normal.

As a result, we determined that, of the trace elements, selenium was lower in the serum of the IS patients. This is the first study in Turkey that we know of about this subject and we think that further studies are needed. At this point, because of contradictory results in the literature, we cannot suggest that selenium support should be given in the early childhood period to prevent selenium deficiency. However variations in selenium levels may be considered a risk factor of adolescent scoliosis. More studies are needed in this subject. 


\section{LIMITATION OF THE STUDY}

The main limitation of this study is the timelimited monitoring of the trace element levels of the patients. The trace elements were measured during the time of application to our hospital, but since the histories of the patients are not known until they apply to a hospital, long-term monitoring of their trace element levels is difficult. We also did not measure vitamin D levels in patients, which are considered to be another factor that may influence IS development.

The study was presented at 49. Turkish Pediatric Congress (İstanbul 2013)

Declaration of Conflicting Interests: The authors declare that they have no conflict of interest.

Financial Disclosure: No financial support was received.

\section{REFERENCES}

1. Moreau A, Akoumé Ndong MY, Azeddine B, et al. Molecular and genetic aspects of idiopathic scoliosis. Blood test for idiopathic scoliosis. Orthopade. 2009; 38:114-6.

2. Grivas TB, Vasiliadis E, Savvidou OD, Triantafyllopoulos G. What a school screening program could contribute in clinical research of idiopathic scoliosis etiology. Disabil Rehabil. 2008; 30:752-62.

3. Ciftci T, Guneri A, Daskaya H. General anesthesia for acute appendicitis operation in a patient with kyphoscoliosis. Dicle Medical J. 2014; 41:391-3.

4. de Sèze M, Cugy E. Pathogenesis of idiopathic scoliosis: a review. Ann Phys Rehabil Med. 2012;55:128-38.

5. Ibisoglu YU, Calıs F, On A. Scoliosis prevalence in the 12-14 years old children in elementary schools in Bornova, İzmir. Türk Fiz Tıp Rehab Derg. 2012; 58:10913.

6. Sud A, Tsirikos AI. Current concepts and controversies on adolescent idiopathic scoliosis: Part I. Indian J Orthop. 2013; 47:117-28.

7. Saikia K C, Duggal A, Bhattacharya P K, Borgohain M. Scoliosis: An epidemiological study of school children in lower Assam. Indian J Orthop. 2002; 36:243-5.
8. Cilli K, Tezeren G, Tas T, et al. School screening for scoliosis in Sivas, Turkey. Acta Orthop Traumatol Turc.2009; 43:426-30.

9. Bridwell KH. Surgical treatment of idiopathic adolescent scoliosis. Spine. 1999; 24:2607-16.

10. Dastych M, Cienciala J. Idiopathic scoliosis and concentrations of zinc, copper, and selenium in blood plasma. Biol Trace Elem Res. 2002; 89:105-10.

11. Lombardi G, Akoume MY, Colombini A, Moreau A Banfi G. Biochemistry of adolescent idiopathic scoliosis. Adv Clin Chem. 2011; 54:165-82.

12. Kouwenhoven JW, Castelein RM. The pathogenesis of adolescent idiopathic scoliosis: review of the literature. Spine. 2008; 33:2898-908.

13. Dayer $R$, Haumont $T$, Belaieff $W$, Lascombes $P$. Idiopathic scoliosis: Etiological concepts and hypotheses. J Child Orthop. 2013; 7:11-6.

14. Dastych M, Cienciala J, Krbec M. Changes of selenium, copper, and zinc content in hair and serum of patients with idiopathic scoliosis. J Orthop Res. 2008; 26:127982.

15. Yang $C$, Niu $C$, Bodo $M$, et al. Fulvic acid supplementation and selenium deficiency disturb the structural integrity of mouse skeletal tissue. An animal model to study the molecular defects of Kashin-Beck disease. Biochem J. 1993; 289:829-35.

16. Ren FL, Guo X, Zhang RJ, et al. Effects of selenium and iodine deficiency on bone, cartilage growth plate and chondrocyte differentiation in two generations of rats. Osteoarthritis Cartilage. 2007;15:1171-7.

17. Yang Z, Xie Y, Chen J, et al. High selenium may be a risk factor of adolescent idiopathic scoliosis. Med Hypotheses. 2010; 75:126-7.

18. Ji XR, Yang ZD, Yang XH, et al. Change of selenium in environment and risk of adolescent idiopathic scoliosis: a retrospective cohort study. Eur Rev Med Pharmacol Sci. 2013; 17:2499-503.

19. Oguz E, Ekinci S, Ersen O. Investigation of the radiologic evaluation and classification scheme in adolescence idiopatic scoliosis. TOTBID Dergisi. 2013; 12:73-82.

20. Basu TK, Donaldson D. Intestinal absorption in health and disease: micronutrients. Best Pract Res Clin Gastroenterol. 2003;17:957-79. 
21. Ohyoshi E, Hamada Y, Nakata K, Kohata S. The interaction between human and bovine serum albumin and zinc studied by a competitive spectrophotometry. J Inorg Biochem. 1999; 75:213-8.

22. August D, Janghorbani M, Young VR. Determination of zinc and copper absorption at three dietary $\mathrm{Zn}-\mathrm{Cu}$ ratios by using stable isotope methods in young adult and elderly subjects. Am J Clin Nutr. 1989; 50:1457-63.

23. Guo $\mathrm{CH}$, Chen $\mathrm{PC}$, Yeh $\mathrm{MS}$, et al. $\mathrm{Cu} / \mathrm{Zn}$ ratios are associated with nutritional status, oxidative stress, inflammation, and immune abnormalities in patients on peritoneal dialysis. Clin Biochem. 2011; 44:275-80.
24. Yang C, Wolf E, Röser K, et al. Selenium deficiency and fulvic acid supplementation induces fibrosis of cartilage and disturbs subchondral ossification in knee joints of mice: an animal model study of Kashin-Beck disease. Virchows Arch A Pathol Anat Histopathol. 1993; 423:483-91.

25. Lemly AD. Teratogenic effects of selenium in natural populations of freshwater fish. Ecotox Environ Safe. 1993; 26:181-204.

26. Dastych M, Vlach 0. Zinc status in patients with idiopathic scoliosis. Spine. 1990; 15:65-6. 
Dicle Tıp Dergisi / Dicle Medical Journal

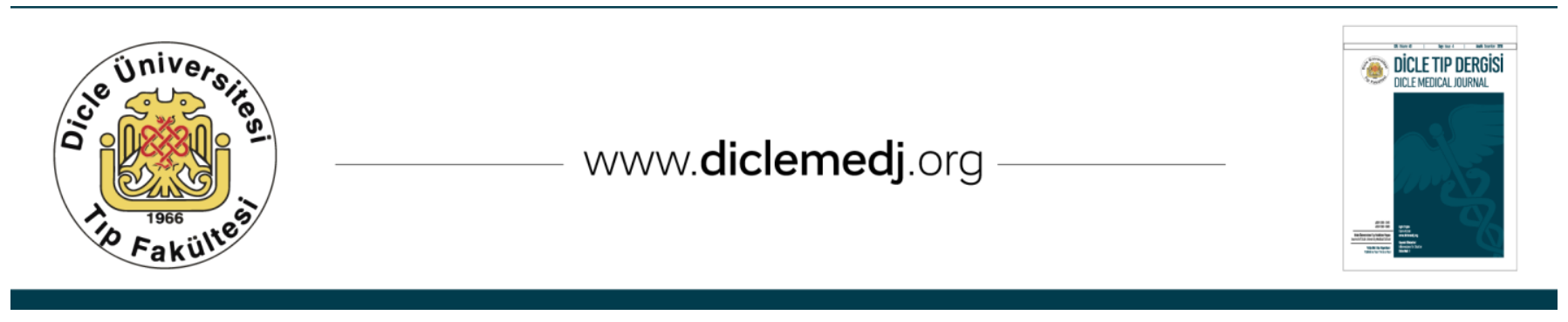

